\title{
Purification and Properties of $\beta$-Lactamases from Serratia marcescens
}

\author{
By M. TAJIMA, ${ }^{*} \dagger$ S. MASUYOSHI, ${ }^{1}$ M. INOUE, ${ }^{2}$ Y. TAKENOUCHI, ${ }^{3}$ \\ S. SUGAWARA ${ }^{3}$ AND S. MITSUHASHI \\ ${ }^{1}$ Department of Microbiology, School of Medicine, Gunma University, Maebashi, \\ Gunma 371, Japan \\ ${ }^{2}$ Laboratory of Drug Resistance in Bacteria, School of Medicine, Gunma University, \\ Maebashi, Gunma 371, Japan \\ ${ }^{3}$ Central Research Laboratories, Sankyo Co. Ltd, Shinagawa-ku, Tokyo 140, Japan
}

(Received 2 December 1980; revised 6 February 1981)

Both a penicillinase and a cephalosporinase were purified from a strain of Serratia marcescens (GN7647) resistant to $\beta$-lactam antibiotics. The penicillinase was identical to the type I penicillinase, mediated by Rms 212 and R-TEM. The purified cephalosporinase, a typical chromosomally mediated enterobacterial $\beta$-lactamase, gave a single protein band on polyacrylamide gel electrophoresis and immunoelectrophoresis; the pI was 9.56 and its molecular weight was approximately 37000 . It contained tryptophan but not cysteine. The specific activity was 374 units (mg protein $)^{-1}$ for the hydrolysis of cephaloridine, and the optimal $\mathrm{pH}$ was $8 \cdot 5$. Rabbit antisera raised against the purified cephalosporinase showed no cross-reaction in a neutralization test with cephalosporinases produced by other species of Enterobacteriaceae.

\section{INTRODUCTION}

$\beta$-Lactam antibiotics showed relatively poor activity against Serratia marcescens (Verbist, 1976). Many strains produce an inducible cephalosporinase which is considered to be the 'species-specific' $\beta$-lactamase (Sawai et al., 1968). Ito et al. (1980) reported that many strains of $S$. marcescens possess a penicillinase mediated by a plasmid. Some properties of the $\beta$-lactamases from $S$. marcescens have been investigated (Tsang et al., 1975; Farrar \& O'Dell, 1976) and compared with $\beta$-lactamases of other bacteria, using crude enzyme preparations (Sawai et al., 1968).

In the present work, we have studied some of the physical, chemical and immunological properties of two $\beta$-lactamases produced by a strain of $S$. marcescens.

\section{METHODS}

Antibiotics. The $\beta$-lactam antibiotics used (see Results) were gifts from their respective manufacturers.

Bacterial strains and identification. All the strains of Serratia marcescens studied were isolated from clinical sources and were maintained in cooked meat medium (Eiken Chemical Co., Tokyo, Japan). Species were identified according to the scheme of Cowan \& Steel (1974).

Antibiotic resistance. Minimum inhibitory concentrations of various $\beta$-lactam antibiotics were determined by using twofold dilutions in heart infusion agar (Eiken Chemical Co.) with an inoculum of $10^{4}$ organisms.

Culture and harvesting of organisms. Trypto-soy broth $(21$; Eiken Chemical Co.) in a 51 flask was inoculated with $100 \mathrm{ml}$ of an overnight culture at $37^{\circ} \mathrm{C}$ and incubated on a rotary shaker at $37^{\circ} \mathrm{C}$. After $4 \mathrm{~h}$, the bacteria were harvested by centrifuging and washed once with $0.15 \mathrm{M}-\mathrm{NaH}_{2} \mathrm{PO}_{4} / \mathrm{Na}_{2} \mathrm{HPO}_{4}$ buffer, pH 7.5. The packed

$\dagger$ Present address: Central Research Laboratories, Sankyo Co. Ltd, 1-2-58 Hiromachi, Shinagawa-ku, Tokyo 140, Japan. 


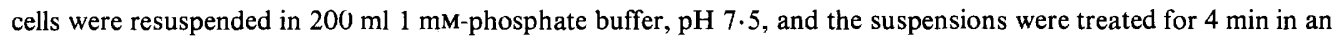
ultrasonic disintegrator $(80 \mathrm{~W}, 25 \mathrm{kHz})$. The disrupted suspensions were centrifuged at $10000 \mathrm{~g}$ for $20 \mathrm{~min}$ at $5{ }^{\circ} \mathrm{C}$ to remove unbroken cells and cell debris; the cell-free extract was retained as the crude enzyme preparation. Protein was determined by the Lowry method.

Purification of $\beta$-lactamases. (All buffer solutions were $\mathrm{NaH}_{2} \mathrm{PO}_{4} / \mathrm{Na}_{2} \mathrm{HPO}_{4}$ unless otherwise stated.) To the cell-free extract, streptomycin sulphate was added to give $1.5 \%(\mathrm{w} / \mathrm{v})$. After removing the precipitate by centrifuging $(10000 \mathrm{~g}, 20 \mathrm{~min})$, the supernatant was dialysed overnight against distilled water and then against 21 $5 \mathrm{~mm}$ buffer, $\mathrm{pH} 7 \cdot 2$. The precipitate formed during dialysis was removed by centrifuging and the supernatant was passed through a CM-Sephadex C-50 column $(2 \cdot 3 \times 30 \mathrm{~cm})$ equilibrated with $5 \mathrm{mM}$ buffer, $\mathrm{pH} 7 \cdot 2$. The eluate was monitored by recording the absorbance at $280 \mathrm{~nm}$. The first peak contained a large amount of inactive protein and a plasmid-mediated penicillinase. The chromosomal cephalosporinase appeared in the second peak after elution with $0.1 \mathrm{M}$ buffer, $\mathrm{pH} 7 \cdot 2$; the active fraction was retained as the 'partially purified' enzyme preparation.

The first peak was applied to a DEAE-Sephadex A-50 column $(2.3 \times 20 \mathrm{~cm})$ and after washing with $200 \mathrm{ml}$ $0.01 \mathrm{M}$ buffer, $\mathrm{pH} 7.2$, was eluted with a $400 \mathrm{ml}$ linear gradient of 0.01 to $0.1 \mathrm{M}$-phosphate buffer, $\mathrm{pH} 7.2$. The second peak was applied to another column of CM-Sephadex C-50 $(2.3 \times 20 \mathrm{~cm})$ and after washing with $200 \mathrm{ml} 0.01 \mathrm{M}$ buffer, $\mathrm{pH} 7 \cdot 2$, was eluted with a $400 \mathrm{ml}$ linear gradient of 0.01 to $0.1 \mathrm{M}$-phosphate buffer, $\mathrm{pH} 7.2$. The active fractions (for penicillinase, those eluted with 0.048 to $0.055 \mathrm{M}$ buffer; for cephalosporinase, those eluted with 0.060 to $0.068 \mathrm{M}$ buffer) were pooled and then dialysed against distilled water. The dialysed solutions were used for isoelectric focusing (see below). In each case, fractions around the peak of enzyme activity were pooled and applied to a Sephadex G-200 column $(2.3 \times 86 \mathrm{~cm})$ equilibrated with $0.05 \mathrm{M}$-Tris $/ \mathrm{HCl} / 0.1 \mathrm{M}-\mathrm{NaCl}$ buffer, $\mathrm{pH} 8.0$, and eluted with the same buffer. Active fractions were dialysed against distilled water and then lyophilized.

Isoelectric focusing. Isoelectric focusing was performed on a sucrose/ampholytes gradient ( $\mathrm{pH} 3 \cdot 5$ to 10). The experiments were carried out at $5{ }^{\circ} \mathrm{C}$ in the LKB 8100 column as previously reported (Tajima et al., 1980).

Polyacrylamide gel electrophoresis. The purity of the enzyme preparations was checked by discontinuous gel electrophoresis as described by Davis (1964), using $7.5 \%(\mathrm{w} / \mathrm{v})$ polyacrylamide gel, $\mathrm{pH} 4 \cdot 3$, as the separation gel. Electrophoresis was carried out in duplicate gels: one was stained with Coomassie Brilliant Blue R250 and the other was cut into slices $4 \mathrm{~mm}$ thick. The slices were disrupted in $1 \mathrm{ml} 0.01 \mathrm{M} \mathrm{buffer}$, $\mathrm{pH} 7 \cdot 5$, and the $\beta$-lactamase activity was measured.

Determination of molecular weight. The molecular weight of the enzymes was determined by gel filtration through Sephadex G-200 with 0.05 M-Tris/HCl/0.1 M- NaCl buffer, pH 8.0, as described by Andrews (1964), and by sodium dodecyl sulphate (SDS)-polyacrylamide slab gel electrophoresis according to Weber \& Osborn (1969), using bovine serum albumin (mol. wt 67000), ovalbumin (45000), chymotrypsinogen (25 700) and lysozyme (14400) as molecular weight standards.

Assay of $\beta$-lactamase. Hydrolysis of $\beta$-lactam antibiotics was assayed spectrophotometrically (O'Callaghan et al., 1969; Waley, 1974; Tajima et al., 1980) by measuring the decrease in absorbance at the substrate specific wavelength at $30^{\circ} \mathrm{C}$ in $3 \mathrm{ml} 0.01 \mathrm{M}-\mathrm{NaH}_{2} \mathrm{PO}_{4} / \mathrm{Na}_{2} \mathrm{HPO}_{4}$ buffer, $\mathrm{pH} 7 \cdot 5$. One unit of $\beta$-lactamase activity is defined as the amount catalysing the hydrolysis of $1 \mu \mathrm{mol}$ substrate $\min ^{-1}$, and activities are expressed as units (mg enzyme protein) $)^{-1}$.

Substrate profile. The substrate profile of 'partially purified' enzyme preparations was determined with cephaloridine, cefazolin, cephalothin, cephalexin, cefotiam, cefmetazole and penicillin $G$. The rate of hydrolysis of each antibiotic was calculated relative to the rate of hydrolysis of cephaloridine which was given an arbitrary value of 100 .

Estimation of kinetic parameters. Using the purified enzyme preparation, the $K_{\mathrm{m}}$ and $V_{\max }$ values for several substrates were estimated from Lineweaver-Burk plots. The $K_{\mathrm{m}}$ values are expressed as $\mu \mathrm{M}$ and the $V_{\max }$ values as $\mu \mathrm{mol}$ substrate hydrolysed $\mathrm{min}^{-1}$ (mg protein) $)^{-1}$. The $K_{1}$ values were determined from LineweaverBurk plots at various concentrations of inhibitors, using cephaloridine as the substrate.

Immunological methods. Rabbit antisera were raised against the purified cephalosporinase as previously reported (Tajima et al., 1980). The effect of the antibodies on $\beta$-lactamase was determined by a neutralization test of the hydrolysing activity of the enzyme (Jack \& Richmond, 1970; Tajima et al., 1980). Immunoelectrophoresis was done in $1.2 \%(\mathrm{w} / \mathrm{v})$ agar containing veronal buffer, $\mathrm{pH} 8.6$.

Amino acid analysis. The amino acid composition of the enzymes was determined as described by Spackman et al. (1958) and as previously reported (Fujii-Kuriyama et al., 1977), with an amino acid analyser (Hitachi model KLA-2).

\section{RESULTS}

\section{Resistance levels and $\beta$-lactamase activities}

All of 21 strains of Serratia marcescens examined had a high degree of resistance to cefazolin and ampicillin (minimum inhibitory concentrations $>400 \mu \mathrm{g} \mathrm{ml}^{-1}$ ). Their 
Table 1. Summary of the purification of cephalosporinase from S. marcescens strain GN7647

These results were obtained for purification from a 161 culture $\left(100 \mu \mathrm{g}\right.$ cefmetazole $\mathrm{ml}^{-1}$ added as an inducer) of strain GN7647. Activity was determined with $100 \mu \mathrm{M}$-cephaloridine as substrate.

Procedure

1. Ultrasonic disintegration

2. Streptomycin treatment

3. Chromatography on CM-Sephadex

4. Re-chromatography on CM-Sephadex

5. Isoelectric focusing

6. Gel filtration on Sephadex G-200 and lyophilized

$\begin{array}{ccc}\begin{array}{c}\text { Total protein } \\ (\mathrm{mg})\end{array} & \begin{array}{c}\text { Specific activity } \\ \text { (units } \mathrm{mg}^{-1} \text { ) }\end{array} & \begin{array}{c}\text { Recovery } \\ (\%)\end{array} \\ 7700 & 6 \cdot 0 & 100 \\ 3455 & 10 & 74 \cdot 8 \\ 162 \cdot 2 & 178 & 62 \cdot 5 \\ 79 \cdot 5 & 251 & 43 \cdot 2 \\ 50 \cdot 8 & 332 & 36 \cdot 5 \\ 37.5 & 374 & 30 \cdot 4\end{array}$

$\beta$-lactamase activities ranged from $<0.1$ to 1.72 units (mg protein) ${ }^{-1}: 10$ of the strains had activities of more than 1 unit (mg protein) $)^{-1}$.

The substrate profiles of the 'partially purified' enzyme preparations (see Methods) from these strains were all similar. The $\beta$-lactamases hydrolysed cephaloridine (rate of hydrolysis $=$ 100 ), cefazolin (289 to 330 ), cephalothin (334 to 413 ), cephalexin (20 to 30) and cefotiam (52 to 77). Cefmetazole and penicillin $G$ were not hydrolysed.

Serratia marcescens GN7647 had the highest enzyme activity [1.72 units (mg protein) $\left.{ }^{-1}\right]$, and therefore this strain was used as a source for purification of $\beta$-lactamase.

\section{Separation and purification of two $\beta$-lactamases}

The cephalosporinase and the penicillinase were separated by chromatography on a column of CM-Sephadex (see Methods). The cephalosporinase was further purified as indicated in Table 1 and as previously reported (Tajima et al., 1980). The purity of the lyophilized preparation was checked by polyacrylamide gel electrophoresis, SDSpolyacrylamide slab gel electrophoresis and immunoelectrophoresis. In polyacrylamide gel electrophoresis the enzyme activity and the stained band coincided, and SDS-polyacrylamide slab gel electrophoresis gave a single protein band. Agar gel immunoelectrophoresis using the anti-GN7647-cephalosporinase sera and the crude enzyme preparation of $S$. marcescens GN7647 gave a single precipitin arc, showing that the antisera contained a single component reacting with crude enzyme preparation; moreover, the precipitin arc for the antisera and the purified enzyme preparation was symmetrical with that of the crude enzyme preparation. These results indicated that the purified enzyme preparation was homogeneous.

Likewise, for the purified penicillinase [specific activity 1506 units (mg protein) ${ }^{-1}$ ], the enzyme activity and the stained band coincided after polyacrylamide gel electrophoresis and a single protein band was detected after SDS-polyacrylamide slab gel electrophoresis.

\section{Physicochemical properties of the purified enzymes}

The molecular weight of the purified cephalosporinase determined by gel filtration through Sephadex G-200 was 37000, and from its electrophoretic mobility in the SDS-polyacrylamide slab gel the subunit molecular weight of the enzyme was also estimated to be 37000. Neutral sugar was not detectable in the purified enzyme by the phenol/sulphuric acid method (Dubois et al., 1956). These results show that the purified enzyme is composed of a single polypeptide of molecular weight 37000 . The amino acid composition of the purified enzyme is given in Table 2: the enzyme contained tryptophan but not cysteine. Its pI was 9.56 .

The penicillinase was found to be a single polypeptide with a molecular weight of about 26000 . It contained cysteine but not tryptophan, and its pI was $5 \cdot 10$. 
Table 2. Amino acid composition of cephalosporinase from $S$. marcescens strain GN7647

\begin{tabular}{|c|c|c|}
\hline Amino acid & $\begin{array}{c}\text { Content } \\
\left(\mu \mathrm{mol} \mathrm{mg}^{-1}\right)\end{array}$ & Residues* \\
\hline Aspartic acid & 0.827 & 35 \\
\hline Threonine & 0.436 & 18 \\
\hline Serine & 0.396 & 17 \\
\hline Glutamic acid & 0.817 & 34 \\
\hline Proline & 0.601 & 25 \\
\hline Glycine & 0.677 & 28 \\
\hline Alanine & 0.921 & 39 \\
\hline Cysteine & 0 & 0 \\
\hline Valine & 0.535 & 19 \\
\hline Methionine & 0.296 & 12 \\
\hline Isoleucine & $0 \cdot 365$ & 15 \\
\hline Leucine & 0.659 & 28 \\
\hline Tyrosine & 0.479 & 20 \\
\hline Phenylalanine & 0.226 & 10 \\
\hline Tryptophan & $0 \cdot 102$ & 4 \\
\hline Lysine & 0.437 & 18 \\
\hline Histidine & 0.096 & 4 \\
\hline Arginine & 0.288 & 12 \\
\hline Total & $8 \cdot 160$ & 338 \\
\hline
\end{tabular}

* The calculated numbers of residues are based on assumed molecular weight of 37000 .

Table 3. Kinetics of hydrolysis of $\beta$-lactam antibiotics by $\beta$-lactamases from $S$. marcescens strain GN7647

\begin{tabular}{|c|c|c|c|c|c|c|}
\hline \multirow[b]{2}{*}{ Antibiotic } & \multicolumn{3}{|c|}{ Cephalosporinase } & \multicolumn{3}{|c|}{ Penicillinase } \\
\hline & $V_{\max }{ }^{*}$ & $K_{\mathrm{m}}(\mu \mathrm{M})$ & $K_{1} \dagger(\mu \mathrm{M})$ & $V_{\max }{ }^{*}$ & $K_{\mathrm{m}}(\mu \mathrm{M})$ & $K_{1} \dagger(\mu \mathrm{M})$ \\
\hline Cephaloridine & 100 & 267 & - & 46 & 286 & - \\
\hline Cefazolin & 645 & 571 & - & $8 \cdot 4$ & 182 & - \\
\hline Cephalothin & 87 & 56 & - & $4 \cdot 0$ & - & - \\
\hline Cephalexin & $4 \cdot 3$ & - & - & 0.1 & - & - \\
\hline Cephradine & $4 \cdot 0$ & - & - & 0.1 & 一 & - \\
\hline Cefamandole & 30 & 174 & - & 12 & 46 & - \\
\hline Cefoperazone & 14 & 8 & - & 17 & 167 & $\ldots$ \\
\hline Cefotiam & 56 & 17 & - & 1.6 & - & - \\
\hline Cefuroxime & 0.5 & - & 0.22 & 0 & 一 & $>100$ \\
\hline Cefotaxime & 0.6 & - & $1 \cdot 1$ & 0 & - & - \\
\hline Ceftizoxime & $2 \cdot 2$ & - & 7.7 & 0 & - & - \\
\hline Cefmenoxime & 0.2 & - & 0.45 & $0 \cdot 1$ & - & - \\
\hline Cefoxitin & 0 & - & 0.45 & 0 & - & $>100$ \\
\hline Cefmetazole & 0 & - & 0.41 & 0 & 一 & - \\
\hline Moxalactam & 0 & - & $7 \cdot 8$ & 0 & - & $>100$ \\
\hline Penicillin G & $2 \cdot 5$ & - & - & 100 & 63 & - \\
\hline Ampicillin & 0 & - & 0.005 & 99 & 49 & - \\
\hline Carbenicillin & 0 & - & 0.07 & $9 \cdot 0$ & - & - \\
\hline Cloxacillin & 0 & - & 0.001 & $0 \cdot 1$ & - & 25 \\
\hline Methicillin & 0 & - & 0.34 & 0 & - & 0.29 \\
\hline
\end{tabular}

* $V_{\max }$ values are given relative to an arbitrary value of 100 for hydrolysis of cephaloridine or penicillin $\mathrm{G}$, as appropriate.

$\dagger K_{\mathrm{f}}$ values were determined from Lineweaver-Burk plots at various concentrations of inhibitors, using cephaloridine as the substrate.

Enzymic properties of the purified enzymes

The $\mathrm{pH}$-activity curve for the cephalosporinase was relatively sharp and had a maximum near $\mathrm{pH} 8.5$. The curve for the penicillinase was rather broad and had a maximum at about $\mathrm{pH} 6 \cdot 5$. 
The kinetic parameters of the enzyme activities towards cephalosporins, cephamycins and penicillins are given in Table 3 . For the cephalosporinase, the relative $V_{\max }$ with cefazolin, cephaloridine, cephalothin, cefotiam, cefamandole and cefoperazone was higher than with penicillins. Among the cephalosporin derivatives tested, cefuroxime, cefotaxime and cefmenoxime were resistant to hydrolysis by the cephalosporinase, and cephamycins and semi-synthetic penicillins were not hydrolysed at all. Moreover, cephamycins inhibited the enzyme activity of the cephalosporinase competitively. It is interesting to note that cloxacillin completely inhibited the activity of the cephalosporinase but only partially inhibited the activity of the penicillinase. The penicillinase hydrolysed ampicillin and carbenicillin, and also cephalosporins such as cephaloridine, cefoperazone, cefamandole, cefazolin and cephalothin.

\section{Immunological properties of the cephalosporinase}

The neutralizing capacity of the antisera was checked with chromosomally mediated enterobacterial $\beta$-lactamases obtained from various clinical isolates (five Serratia marcescens, two Pseudomonas aeruginosa, two Enterobacter cloacae, one Proteus morganii, one Proteus vulgaris, one Proteus rettgeri, one Bacteroides fragilis) and with four types of R-plasmidmediated penicillinase from R-plasmid-carrying Escherichia coli. The antisera neutralized completely (98 to $100 \%$ ) cephalosporinase from $S$. marcescens strains; none of the other $\beta$-lactamases were affected at all.

\section{DIS C USSION}

Farrar \& O'Dell (1976) reported that strains of $S$. marcescens fall into two groups with respect to their resistance to $\beta$-lactam antibiotics. Strains in one group produce small amounts of an inducible cephalosporinase, which appears to be chromosomally mediated. Strains in the other group produce large amounts of a non-inducible penicillinase-cephalosporinase, which is plasmid-mediated.

In the present study, both a penicillinase and a cephalosporinase were purified from a strain of $S$. marcescens GN7647. By combining several methods, including isoelectric focusing and neutralization with antisera, we have characterized differences in isoelectric point, molecular weight and immunological properties of $\beta$-lactamases in $S$. marcescens.

The purified cephalosporinase from $S$. marcescens GN7647 showed the same general properties as for typical cephalosporinases described by Sawai et al. (1968) and for class I $\beta$-lactamases described by Richmond \& Sykes (1973). As indicated by $V_{\max }$ values, this enzyme has a high activity on cephalosporin derivatives and a low activity for semi-synthetic penicillins, some novel cephalosporins and cephamycins. It has been reported by numerous investigators (O'Callaghan \& Muggleton, 1967; Jack \& Richmond, 1970; Yaginuma et al., 1973; Richmond \& Sykes, 1973; Fujii-Kuriyama et al., 1977; Tajima et al., 1980; Minami et al., 1980) that semi-synthetic penicillins, particularly cloxacillin, methicillin and carbenicillin, are not only resistant to hydrolysis by cephalosporinase but are strong inhibitors of the enzyme activity. These semi-synthetic penicillins inhibited the purified enzyme of $S$. marcescens strain GN7647 in a competitive manner, as did cefuroxime, cefmenoxime and cephamycins such as cefoxitin and cefmetazole. The $K_{\mathrm{f}}$ values of these $\beta$-lactamase-stable cephalosporins and cephamycins were comparable with that of methicillin.

The purified cephalosporinase had a molecular weight of 37000 and its isoelectric point was 9.56. The chromosomally mediated cephalosporinases purified from Pseudomonas aeruginosa GN918 (Yaginuma et al., 1973), Proteus morganii 1510 (Fujii-Kuriyama et al., 1977), Citrobacter freundii GN7391 (Tajima et al., 1980) and Escherichia coli GN5482 (Minami et al., 1980) have molecular weights of 34000, 38000, 38000 and 39000 , respectively. The molecular weight of the purified enzyme of $S$. marcescens GN7647 is thus close to those of other cephalosporinases. However, the isoelectric point for the purified 
enzyme was more basic than those of other cephalosporinases (pI 7.2 to 8.7). Matthew \& Harris (1976) reported that $\beta$-lactamases from $S$. marcescens strains $1324 \mathrm{E}$ and $1331 \mathrm{E}$ had pI values of 8.2 and $8 \cdot 5$, respectively. Sykes \& Matthew (1976) reported that the $\beta$ lactamase from strain $1331 \mathrm{E}$ hydrolysed cloxacillin, but our purified enzyme did not hydrolyse it significantly.

The cephalosporinase protein of strain GN7647 was detected among other strains of $S$. marcescens, such as $1823,1831,1840,1845$ and $\mathrm{GN} 10857$, isolated from clinical material, by the immunoelectrophoretic analysis and neutralization test.

The penicillinase from $S$. marcescens strain GN7647 was identical to type I penicillinases described by Sawai et al. (1970) and class III $\beta$-lactamases described by Richmond \& Sykes (1973).

We thank Dr Y. Baba for carrying out the amino acid analyses.

\section{REFERENCES}

ANDrews, P. (1964). Estimation of the molecular weight of proteins by Sephadex gel filtration. Biochemical Journal 91, 222-233.

CowAN, S. T. \& STEEL, K. J. (1974). Manual for the Identification of Medical Bacteria, 2nd edn. Cambridge: Cambridge University Press.

Davis, B. J. (1964). Disc electrophoresis II. Method and application to human serum proteins. Annals of the New York Academy of Sciences 121, 404427.

Dubois, M., Gilles, K. A., Hamilton, J. K., Rebers, P. A. \& SмIтh, F. (1956). Colorimetric method for determination sugars and related substances. Analytical Chemistry 28, 350-356.

FARRAR, W. E., JR \& O'Dell, N. M. (1976). $\beta$ Lactamases and resistance to penicillins and cephalosporins in Serratia marcescens. Journal of Infectious Diseases 134, 245-251.

Fuji-Kuriyama, Y., Yamamoto, M. \& Sugawara, S. (1977). Purification and properties of betalactamase from Proteus morganii. Journal of Bacteriology 131, 726-734.

Ito, A., Ito, J., Inoue, M. \& Mitsuhashi, S. (1980). Epidemiological studies on drug resistance plasmids isolated from strains of Serratia marcescens. Japanese Journal of Microbiology 35, 796.

JACK, G. W. \& RICHMOND, M. H. (1970). A comparative study of eight distinct $\beta$-lactamases synthesized by Gram-negative bacteria. Journal of General Microbiology 61, 43-61.

MATTHEW, M. \& HARRIS, A. M. (1976). Identification of $\beta$-lactamases by analytical isoelectric focusing: correlation with bacterial taxonomy. Journal of General Microbiology 94, 55-67.

Minami, S., Inoue, M. \& Mitsuhashi, S. (1980). Purification and properties of cephalosporinase in Escherichia coli. Antimicrobial Agents and Chemotherapy 18, 77-80.

O'Callaghan, C. H. \& Muggleton, P. W. (1967). The action of cephaloridine with cloxacillin or methicillin against $\beta$-lactamase-producing Gramnegative bacteria. Journal of General Microbiology 48, 449-460.

O'Callaghan, C. H., Muggleton, P. W. \& Ross, G. W. (1969). Effects of $\beta$-lactamase from Gramnegative organisms on cephalosporins and penicillins. In Antimicrobial Agents and Chemotherapy-1968, pp. 55-63. Edited by G. L. Hobby. Maryland: American Society for Microbiology.
RICHMOND, M. H. \& SYKeS, R. B. (1973). The $\beta$-lactamases of Gram-negative bacteria and their possible physiological role. Advances in Microbial Physiology 9, 31-88.

Sawai, T., Mitsuhashi, S. \& Yamagishi, S. (1968). Drug resistance of enteric bacteria. XIV. Comparison of $\beta$-lactamases in Gram-negative rod bacteria resistant to $\alpha$-aminobenzylpenicillin. Japanese Journal of Microbiology 12, 423-434.

SaWaI, T., Takahashi, K., Yamagishi, S. \& MitsuhASHI, S. (1970). Variant of penicillinase mediated by an $\mathrm{R}$ factor in Escherichia coli. Journal of Bacteriology 104, 620-629.

Spackman, D. H., Stein, W. H. \& Moore, S. (1958). Automatic recording apparatus for use in the chromatography of amino acid. Analytical Chemistry 30, 1190-1206.

Sykes, R. B. \& MatThew, M. (1976). The $\beta$ lactamases of Gram-negative bacteria and their role in resistance to $\beta$-lactam antibiotics. Journal of Antimicrobial Chemotherapy 2, 115-157.

TAJIMA, M., TAKenouchI, Y., Sugawara, S., Inoue, M. \& Mitsuhashi, S. (1980). Purification and properties of chromosomally mediated $\beta$ lactamase from Citrobacter freundii GN7391. Journal of General Microbiology 121, 449-456.

Tsang, J. C., Sansing, G. A. \& Miller, M. A. (1975). Relation of beta-lactamase activity to antimicrobial susceptibility in Serratia marcescens. Antimicrobial Agents and Chemotherapy 8, 277281.

VERBIST, L. (1976). Comparison of the antibacterial activity of nine cephalosporins against Enterobacteriaceae and nonfermentative Gram-negative bacilli. Antimicrobial Agents and Chemotherapy 10, 657-663.

WALEX, S. G. (1974). A spectrophotometric assay of $\beta$-lactamase action on penicillins. Biochemical Journal 139, 789-790.

WEBER, K. \& OsBoRn, M. (1969). The reliability of molecular weight determinations by dodecyl sulfatepolyacrylamide gel electrophoresis. Journal of Biological Chemistry 244, 4406-4412.

Yaginuma, S., Sawai, T., ONo, H., Yamagishi, S. \& MitsuhaShI, S. (1973). Biochemical properties of a cephalosporin $\beta$-lactamase from Pseudomonas aeruginosa. Japanese Journal of Microbiology 17, 141-149. 